Original Article

\title{
Obtainment and characterization of digestive aspartic proteases from the fish Caranx hippos (Linnaeus, 1766)
}

\author{
Obtenção e caracterização de proteases aspárticas digestórias do peixe Caranx hippos \\ (Linnaeus, 1766)
}

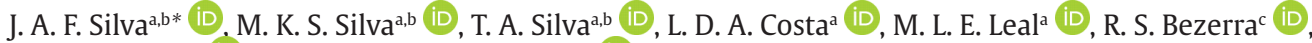 \\ H. M. S. Costa ${ }^{\mathrm{a}, \mathrm{b}}$ (iD and A. C. V. Freitas-Júnior ${ }^{\mathrm{a}, \mathrm{b}}$ (i)
}

aUniversidade Federal da Paraíba - UFPB, Laboratório de Biomoléculas de Organismos Aquáticos, Departamento de Biologia Molecular, Centro de Ciências Exatas e da Natureza, Cidade Universitária, João Pessoa, PB, Brasil

bUniversidade Federal da Paraíba - UFPB, Centro de Ciências Exatas e da Natureza, Programa de Pós-graduação em Biologia Celular e Molecular, Cidade Universitária, João Pessoa, PB, Brasil

'Universidade Federal de Pernambuco - UFPE, Centro de Biociências, Departamento de Bioquímica, Laboratório de Enzimologia, Cidade Universitária, Recife, PE, Brasil

\begin{abstract}
This work aimed to obtain aspartic proteases of industrial and biotechnological interest from the stomach of the crevalle jack fish (Caranx hippos). In order to do so, a crude extract (CE) of the stomach was obtained and subjected to a partial purification by salting-out, which resulted in the enzyme extract (EE) obtainment. EE proteases were characterized physicochemically and by means of zymogram. In addition, the effect of chemical agents on their activity was also assessed. By means of salting-out it was possible to obtain a purification of 1.6 times with a yield of $49.4 \%$. Two acid proteases present in the EE were observed in zymogram. The optimum temperature and thermal stability for EE acidic proteases were $55^{\circ} \mathrm{C}$ and $45{ }^{\circ} \mathrm{C}$, respectively. The optimum pH and pH stability found for these enzymes were $\mathrm{pH} 1.5$ and 7.0, respectively. Total inhibition of EE acid proteolytic activity was observed in the presence of pepstatin A. dithiothreitol (DTT) and $\mathrm{Ca}^{2+}$ did not promote a significant effect on enzyme activity. In the presence of heavy metals, such as $\mathrm{Al}^{3+}, \mathrm{Cd}^{2+}$ and $\mathrm{Hg}^{2+}$, EE acidic proteases showed more than $70 \%$ of their enzymatic activity. The results show that it is possible to obtain, from the stomach of $C$. hippos, aspartic proteases with high proteolytic activity and characteristics that demonstrate potential for industrial and biotechnological applications.

Keywords: waste recovery, fish enzymes, marine fish, aspartic proteases.

Resumo

Este trabalho objetivou obter proteases aspárticas de interesse industrial e biotecnológico a partir do estômago do peixe xaréu (Caranx hippos). Para isso, foi obtido um extrato bruto do estômago, o qual foi submetido a uma purificação parcial por salting-out onde se obteve o extrato enzimático (EE). As proteases do EE foram caracterizadas físico-quimicamente e através de zimograma. Além disso, o efeito de agentes químicos sobre sua atividade também foi avaliado. Através de salting-out foi possível obter uma purificação de 1,6 vezes com rendimento de 49,4\%. Foram observadas duas proteases ácidas presentes no EE através de zimograma. A temperatura ótima e a estabilidade térmica para as proteases ácidas do EE foram de $55{ }^{\circ} \mathrm{C}$ e $45{ }^{\circ} \mathrm{C}$, respectivamente. $\mathrm{O} \mathrm{pH}$ ótimo e a estabilidade ao $\mathrm{pH}$ encontrados para estas enzimas foram o pH 1,5 e 7,0, respectivamente. Observou-se a inibição total da atividade proteolítica ácida do EE na presença de pepstatina A. O ditiotreitol (DTT) e o $\mathrm{Ca}^{2+}$ não promoveram efeito significativo na atividade enzimática. Na presença de metais pesados, como $\mathrm{Al}^{3+}, \mathrm{Cd}^{2+} \mathrm{e} \mathrm{Hg}^{2+}$, o EE manteve mais de $70 \%$ de atividade enzimática do EE. Os resultados mostram que é possível obter, a partir do estômago de C. hippos, proteases aspárticas com alta atividade proteolítica e características que demonstram potencial para aplicações industriais e biotecnológicas.
\end{abstract}

Palavras-chave: aproveitamento de resíduos, enzimas de peixe, peixes marinhos, proteases aspárticas.

\section{Introduction}

The crevalle jack fish, Caranx hippos (Linnaeus, 1766), is a migratory species that belongs to the family Carangidae. They are predatory animals, feeding on smaller fish and some invertebrates, and when young they prefer zooplankton and crustaceans (Luque and Alves, 2001). This species has a worldwide distribution and can easily be found in the American continent from the Caribbean to the coast of Uruguay. Hence, it is found throughout the Brazilian coastline (Costa et al., 2013). According to

*e-mail: aleciopb@hotmail.com

Received: February 27, 2020 - Accepted: July 25, 2020

This is an Open Access article distributed under the terms of the Creative Commons Attribution License, which permits unrestricted use, distribution, and reproduction in any medium, provided the original work is properly cited. 
the latest report on extractive fishing and aquaculture carried out in Brazil (Brasil, 2011), the average national production of crevalle jack fish (C. hippos) between 2009 and 2011 was 2,509.1 ton, with no great variation in production during this period.

Asfresh fish is very perishable foods and due to the current market requirements, most of the fish produced for human consumption receives some kind of processing before being commercialized. Consequently, a large amount of processing residues is produced, such as scales, skins, bones and viscera that are often discarded in natura in the environment, causing great pollution (Freitas-Júnior and Bezerra, 2015).

There is a growing need for the discovery of alternative sources for obtaining industrial enzymes and, on account of that, several studies have been carried out to use the viscera of tropical fish captured or produced in Brazil, including $C$. hippos, to obtain these molecules. Such studies have shown that these byproducts are important and low-cost sources for obtaining alkaline digestive peptidases with industrial and biotechnological potential (Espósito et al., 2010; Freitas-Júnior, et al., 2012; Costa et al., 2013; Medeiros et al., 2015; França et al., 2016). However, the obtaining of acidic proteases from the processing residues of these and other species commercialized in the country has been poorly studied.

Acidic proteases, mainly pepsin, in addition to being used in the food industry for the production of protein hydrolysates and dairy products, can also be used to optimize collagen extraction and the production of gelatine from fish (Zhao et al., 2011; Bkhairia et al., 2016). Pepsins and pepsinogens with industrial potential have been isolated and characterized from the gastric mucosa of several fish species (Zhao et al., 2011). However, the yield and the high costs of these purification processes still hinder the use of fish enzymes with a high degree of purity (Freitas-Júnior et al., 2012). However, many industrial applications, such as those mentioned above, do not need to use such pure enzymes (Freitas-Júnior and Bezerra, 2015). Recently, some researchers have shown the potential of using crude or partially purified enzymatic extracts, obtained from the fish stomach, to obtain gelatin and fish collagen (Bkhairia et al., 2016; Acevedo Gomez et al., 2018).

In view of this, the objective of this work was to evaluate the stomach potential of $C$. hippos fish as a source for obtaining acidic proteases with industrial and biotechnological potential.

\section{Material and Methods}

\subsection{Obtaining crevalle jack stomachs and crude extract (CE)}

The stomachs of Caranx hippos were donated by fishmongers in the metropolitan region of the city of João Pessoa, the State of Paraíba, Brazil, and taken under refrigeration at $4{ }^{\circ} \mathrm{C}$ to the Laboratório de Biomoléculas de Organismos Aquáticos (BIOAQUA) at Universidade Federal da Paraíba. In the laboratory, the stomachs were weighed, cut and frozen in liquid nitrogen. After freezing the pieces were crushed and homogenized with $0.15 \mathrm{M} \mathrm{NaCl}$ solution in the proportion of $1: 10(\mathrm{~g} / \mathrm{mL})$. Then, the homogenate was centrifuged for 20 minutes, at $4^{\circ} \mathrm{C}$, at $10,000 \mathrm{~g}$, and the collected supernatant was called crude extract (CE). CE was stored at $-20{ }^{\circ} \mathrm{C}$ until further use.

\subsection{Enzyme activity assay and soluble protein dosage}

The acidic proteolytic activity was determined according to Pavlisko et al. (1997), using as substrate a $2 \%(\mathrm{w} / \mathrm{v})$ hemoglobin solution in $0.03 \mathrm{M} \mathrm{HCl}$. The result was determined in a Multiskan GO microplate reader $\left(\right.$ Thermo $^{\circledR}$ ). One unit of enzymatic activity was determined to be the amount of enzyme capable of promoting a change in absorbance, at $280 \mathrm{~nm}$, of 0.1 per minute of reaction. The concentration of soluble proteins was determined using the method of Bradford (1976), using bovine serum albumin as a standard.

\subsection{Activation of zymogens}

The activation of zymogens, such as pepsinogen, present in $\mathrm{CE}$, was carried out by acidifying it to $\mathrm{pH} 2.0$ by adding $6 \mathrm{M} \mathrm{HCl}$. Afterwards, the CE was incubated for 60 min. at $25{ }^{\circ} \mathrm{C}$. Subsequently, the CE was centrifuged at $10,000 \mathrm{~g}$, at $4{ }^{\circ} \mathrm{C}$, for $10 \mathrm{~min}$., and the supernatant was collected at the end.

\subsection{Partial purification of acidic proteases present in acidified CE}

The acidified CE was subjected to saline precipitation by the addition of ammonium sulfate until $60 \%$ saturation. After $2 \mathrm{~h}$ of incubation at $4{ }^{\circ} \mathrm{C}$, at rest, the mixture was centrifuged at $8,000 \mathrm{~g}$, at $4{ }^{\circ} \mathrm{C}$, for $20 \mathrm{~min}$. After centrifugation, the precipitate was collected, resolubilized in $0.15 \mathrm{M} \mathrm{NaCl}$ solution ( $\mathrm{pH} 2.0$ ) and dialyzed with the same solution for $24 \mathrm{~h}$ at $4{ }^{\circ} \mathrm{C}$. The $0-60 \%$ dialyzed fraction was stored and called Enzyme Extract (EE).

\subsection{Zymogram}

The number of of acidic proteases in EE was determined by zymogram using the methodology described by GarciaCarreño et al. (1993), with modifications, in which after the gel electrophoresis and polyacrylamide run, it was washed in distilled $\mathrm{H}_{2} \mathrm{O}$ and incubated in $0.03 \mathrm{M} \mathrm{HCl}$ for $5 \mathrm{~min}$. at $4{ }^{\circ} \mathrm{C}$. Then the gel was incubated with a $2 \%$ hemoglobin solution in $0.03 \mathrm{M} \mathrm{HCl}$ for $1 \mathrm{~h}$ and $30 \mathrm{~min}$ at $37^{\circ} \mathrm{C}$. After incubation, the gel was washed in distilled $\mathrm{H}_{2} \mathrm{O}$ and stained with Comassie blue R-250 solution.

\subsection{Physicochemical characterization of EE acidic proteases.}

The effects of $\mathrm{pH}$ and temperature on the proteolytic activity of EE were evaluated using the methodology described by Acevedo Gomez et al. (2018), with minor modifications. To determine the optimal temperature and thermal stability, the temperature range of 25 to $70^{\circ} \mathrm{C}$ was used. The optimal $\mathrm{pH}$ and $\mathrm{pH}$ stability determination were performed using the $0.2 \mathrm{M}$ glycine- $\mathrm{HCl}$ ( $\mathrm{pH} 1.5$ to 2.5) and citrate-phosphate ( $\mathrm{pH} 3.0$ to 7.0 ) buffers. The stability tests were carried out for 30 minutes. 


\subsection{Effects of chemical agents on the activity of EE acidic proteases}

The effect of chemical agents on enzyme activity was carried out according to Acevedo Gomez et al. (2018) using a $10 \mathrm{mM}$ solution of aluminum $\left(\mathrm{Al}^{3+}\right)$, copper $\left(\mathrm{Cu}^{2+}\right)$, magnesium $\left(\mathrm{Mg}^{2+}\right)$, lead $\left(\mathrm{Pb}^{2+}\right)$, manganese $\left(\mathrm{Mn}^{2+}\right)$, calcium $\left(\mathrm{Ca}^{2+}\right)$, sodium $\left(\mathrm{Na}^{+}\right)$, mercury $\left(\mathrm{Hg}^{2+}\right)$, cadmium $\left(\mathrm{Cd}^{2+}\right)$ chlorides; the specific inhibitor of aspartic proteases, pepstatin $\mathrm{A}(100 \mu \mathrm{g} / \mathrm{mL})$ and the reducer dithiotreitol (DTT) $1 \mathrm{mM}$.

\subsection{Effect of $\mathrm{NaCl}$}

The effect of $\mathrm{NaCl}$ on the proteolytic activity of EE was evaluated by incubating, for $30 \mathrm{~min}$., at $25^{\circ} \mathrm{C}$, aliquots of the $\mathrm{EE}$, in the proportion of $1: 1(\mathrm{v} / \mathrm{v})$, with $\mathrm{NaCl}$ solution in different concentrations $(10,20$ and $30 \%)(w / v)$, for 30 min. Residual activity was determined at $37{ }^{\circ} \mathrm{C}$ and for 10 minutes, using $2 \%$ hemoglobin as substrate.

\subsection{Statistical analysis}

All the aforementioned analyzes were performed in triplicate $(\mathrm{n}=3)$. All data were analyzed using ANOVA analysis of variance and Tukey's test. The software used was OriginPro ${ }^{\circledR} 8.0$ and all tests were performed with a significance level of $p<0.05$.

\section{Results and discussion}

\subsection{Partial purification of the Crude Extract}

The CE obtained from the stomach of $C$. hippos showed a total specific activity of $439 \mathrm{mU}^{\mathrm{mg}}{ }^{-1}$ (table 1 ). Through a simple step, it was possible to achieve a purification of 1.6 times with a yield of $49.4 \%$. The use of a simple step for partial purification of the crude extract and concentration of enzymes is an economic advantage for the commercial use of this material in industrial processes that do not demand a high degree of purity of the enzymes, such as in the extraction of collagen and production of fermented fish. Acevedo Gomez et al. (2018), through the same process, obtained a yield of $45.1 \%$ and a purification rate of 1.8 times for aspartic proteases from the stomach crude extract of the fish Prochilodus lineatus (Valenciennes, 1836).

\subsection{Zimogram}

It was possible to observe the presence of two acidic proteases, with bands of similar density and closely resembling characteristics of molecular mass and charge in EE (Figure 1). Cao et al. (2011), Wu et al. (2009), and
Zhou et al. (2008) found more than two acidic proteases in the stomachs of the fish Lateolabrax japonicus (Valenciennes, 1828), Anguilla anguilla (Linnaeus, 1758) and Siniperca chuatsi (Basilewsky, 1855), respectively. However, Bkhairia et al. (2016) observed only one protease in the stomach crude extract zymogram of the of Liza aurata (Risso, 1810).

\subsection{Effect of temperature}

Fish are ectothermic animals, that is, they depend on the environment to maintain their body temperature. Therefore, the temperature is an important parameter to be investigated, given the diverse distribution of these animals across the globe. The optimum temperature determined for the maximum activity of EE acidic proteases was $55{ }^{\circ} \mathrm{C}$ (Figure 2A). However, at a $60{ }^{\circ} \mathrm{C}$ temperature, the fraction maintained approximately $50 \%$ of its proteolytic activity, which suggests the possibility to use them in industrial processes that involve mild to moderate heating. Zhao et al. (2011) state that the pepsin optimum temperature of different fish species range from $35{ }^{\circ} \mathrm{C}$ to $55{ }^{\circ} \mathrm{C}$, and that there is a direct relationship between the optimum temperature and the water temperature where these species inhabit. Bkhairia et al. (2016) characterized an acidic protease in the stomach crude extract of $L$. aurata and found the optimum temperature of $40{ }^{\circ} \mathrm{C}$. The same result was found by Bougatef et al. (2008) for Mustelus mustelus (Linnaeus, 1758) pepsins. Acevedo Gomez et al. (2018) obtained digestive aspartic proteases from $P$. lineatus and determined their optimum temperature to be $45{ }^{\circ} \mathrm{C}$. The same result was found for acidic proteases present in the stomach crude extract of Pangasianodon gigas (Chevey, 1931) (Vannabun et al., 2014) and for pepsins from Coryphaenoides pectoralis (Gilbert, 1892) (Klomklao et al., 2007). Pepsins from the stomach of Sparus latus (Houttuyn, 1782) showed optimum temperature of $45^{\circ} \mathrm{C}$ and $50{ }^{\circ} \mathrm{C}$ (Zhou et al., 2007). Similar results were obtained for pepsins from Micropterus salmoides (Lacepède, 1802) (Miura et al., 2015) and (40 and $50{ }^{\circ} \mathrm{C}$ ) and Thunnus alalunga (Bonnaterre, 1788) $\left(50{ }^{\circ} \mathrm{C}\right)$ (Nalinanon et al., 2010). The same result was found for acidic proteases present in the stomach crude extract of Paralichthys orbignyanus (Valenciennes, 1839) (Candiotto et al., 2018).

In the same way, it is important to determine the optimum temperature of these enzymes, it is also necessary to establish their thermal stability in order to use this data in the optimization of their storage, transport and handling conditions, maintaining their native conformation preserved. The EE proteases were stable in the temperature

Table 1. Purification of acidic digestive proteases from the stomach of C. hippos fish.

\begin{tabular}{lccccc}
\hline Process step & Total Activity $(\mathbf{U})$ & Total Protein $(\mathbf{m g})$ & $\begin{array}{c}\text { Specific activity } \\
\left(\mathbf{m U} \cdot \mathbf{m g}^{-1}\right)\end{array}$ & Purification (fold) & Yield (\%) \\
\hline Crude Extract & $1,546 \pm 50$ & $3,523 \pm 102$ & 439 & 1 & 100 \\
EE & $764 \pm 36$ & $1,103 \pm 75$ & 693 & 1.6 & 49.4 \\
\hline
\end{tabular}

* Parameters established for the process yield using $1 \mathrm{~L}$ of crude extract. One unit of enzyme activity was considered to be the amount of enzyme capable of modifying the absorbance in 0.1 per minute of reaction. 


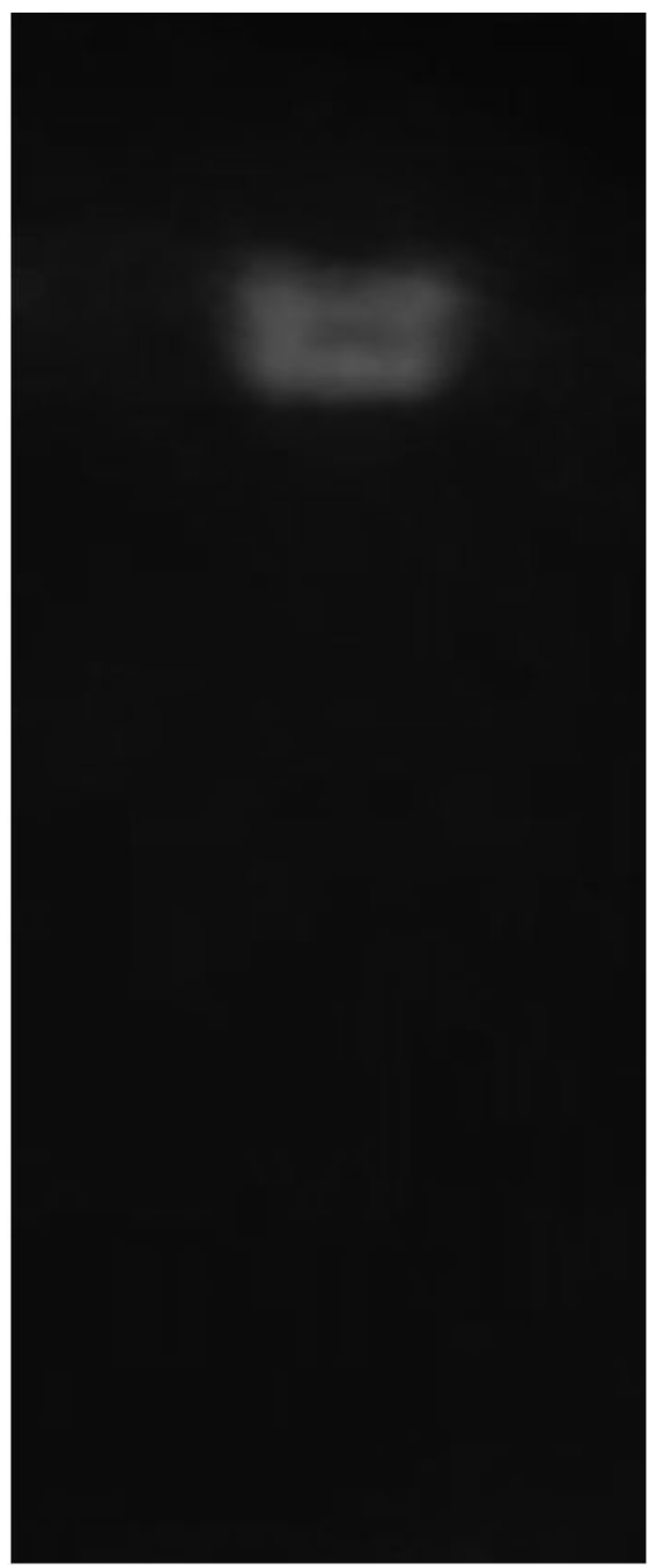

Figure 1. EE Zymogram .

range of $25{ }^{\circ} \mathrm{C}$ to $45{ }^{\circ} \mathrm{C}$ (Figure 2B). Similar results $\left(25{ }^{\circ} \mathrm{C}\right.$ to $40{ }^{\circ} \mathrm{C}$ ) have been reported for acidic digestive proteases of $L$. aurata (Bkhairia et al., 2016) and P. orbignyanus (Candiotto et al., 2018) which were stable up to $40{ }^{\circ} \mathrm{C}$. The same result was observed for pepsins from Sardinella aurita (Valenciennes, 1847)(Khaled et al., 2011) and from C. pectoralis (Klomklao et al., 2007). Acevedo Gomez et al. (2018) observed that $P$. lineatus digestive aspartic proteases were stable up to $37{ }^{\circ} \mathrm{C}$. The T. alalunga and M. mustelus pepsins were stable up to $50^{\circ} \mathrm{C}$ (Bougatef et al., 2008; Nalinanon et al., 2010).

\subsection{Effect of $\mathrm{pH}$ on enzyme extract activity and stability}

Knowledge of the optimum $\mathrm{pH}$ of an enzyme, that is, the $\mathrm{pH}$ in which the enzyme has greater catalytic activity, enables the determination of its potential industrial applications, in addition to providing insights on how to preserve its activity during storage and transportation in solution. The effect of $\mathrm{pH}$ on EE catalytic activity was determined and is shown in Figure 2C. The maximum activity was observed at $\mathrm{pH}$ 1.5. However, at $\mathrm{pH} 4.0$ the proteolytic activity was greater than $80 \%$ demonstrating an optimum $\mathrm{pH}$ range between $\mathrm{pH} 1.5$ and 4.0. Similar results were described by Miura et al. (2015) for two M. Salmoides pepsins (pH 1.5 and 2.0), for P. lineatus (Acevedo Gomez et al., 2018) and P. orbignyanus (Candiotto et al., 2018) digestive acidicproteases ( $\mathrm{pH} 2.0$ ), Bougatef et al. (2008) for M. mustelus pepsins ( $\mathrm{pH} 2.0$ ), Nalinanon et al. (2010) for T. alalunga pepsins ( $\mathrm{pH} 2.0$ ) and Tanji et al. (2007) for Latimeria chalumnae (Smith, 1939) pepsins (pH 2.0). Bkhairia et al. (2016) determined the optimum $\mathrm{pH}$ for L. aurata digestive acidic protease activity as pH 3.0, similarly to the report by Vannabun et al. (2014) for P. gigas digestive acidic proteases and by Khaled et al. (2011) for S. aurita pepsin. Klomklao et al. (2007) and Zhou et al. (2007) determined the maximum activity of C. pectoralis and S. latus pepsins, respectively, at $\mathrm{pH}$ of 3.5.

The $\mathrm{pH}$ stability profile is shown in Figure 2D. The enzymes, after a 30-minute incubation, maintained more than $80 \%$ of activity in the $\mathrm{pH}$ range 1.5 to 7.0 . Since these are acidic proteases, they are not expected to be stable at $\mathrm{pH}$ far from their optimum $\mathrm{pH}$. However, the proteolytic activity of EE was stable in the $\mathrm{pH}$ ranges between 1.5 and 7.0. Bkhairia et al. (2016) report that fish enzymes that inhabit warmer waters can be stable even at neutral $\mathrm{pH}$. The same authors observed a similar result for the digestive acidic protease of $L$. aurata, which was stable in the range of pH 3.0 to 7.0. However, in the study by Klomklao et al. (2007), C. pectoralis pepsins were stable between $\mathrm{pH} 2.0$ and 6.0. A similar result was reported by Nalinanon et al. (2010), in which T. alalunga pepsins were stable in a range of $\mathrm{pH} 2.0$ to 6.0. Bougatef et al. (2008) characterized the pepsins of $M$. mustelus and observed that they remained stable only in the $\mathrm{pH}$ range between 1.0 and 4.0.

The effect of $\mathrm{pH}$ on $\mathrm{C}$. hippos digestive acidic proteases indicates the possibility of storing EE in slightly acidic to neutral $\mathrm{pH}$ without proteolysis or loss of the native structure of these enzymes. In addition, the fact that these enzymes are very active at $\mathrm{pH} 4.0$ indicates the possibility of their use in industrial and biotechnological processes that use weak acids, as in the extraction of collagen where acetic acid is used.

\subsection{Effect of chemical agents on EE acidic proteases}

The effect of some chemical agents on the EE acidic proteolytic activity is shown in Table 2. The effect of the specific aspartic protease inhibitor (which includes pepsin), pepstatin $A$, was evaluated on the activity of the enzymes present in the EE. Total inhibition of acidic proteolytic activity was observed in the presence of this inhibitor. According to Motwani et al. (2015), pepstatin A binds to the active enzyme site and prevents the 

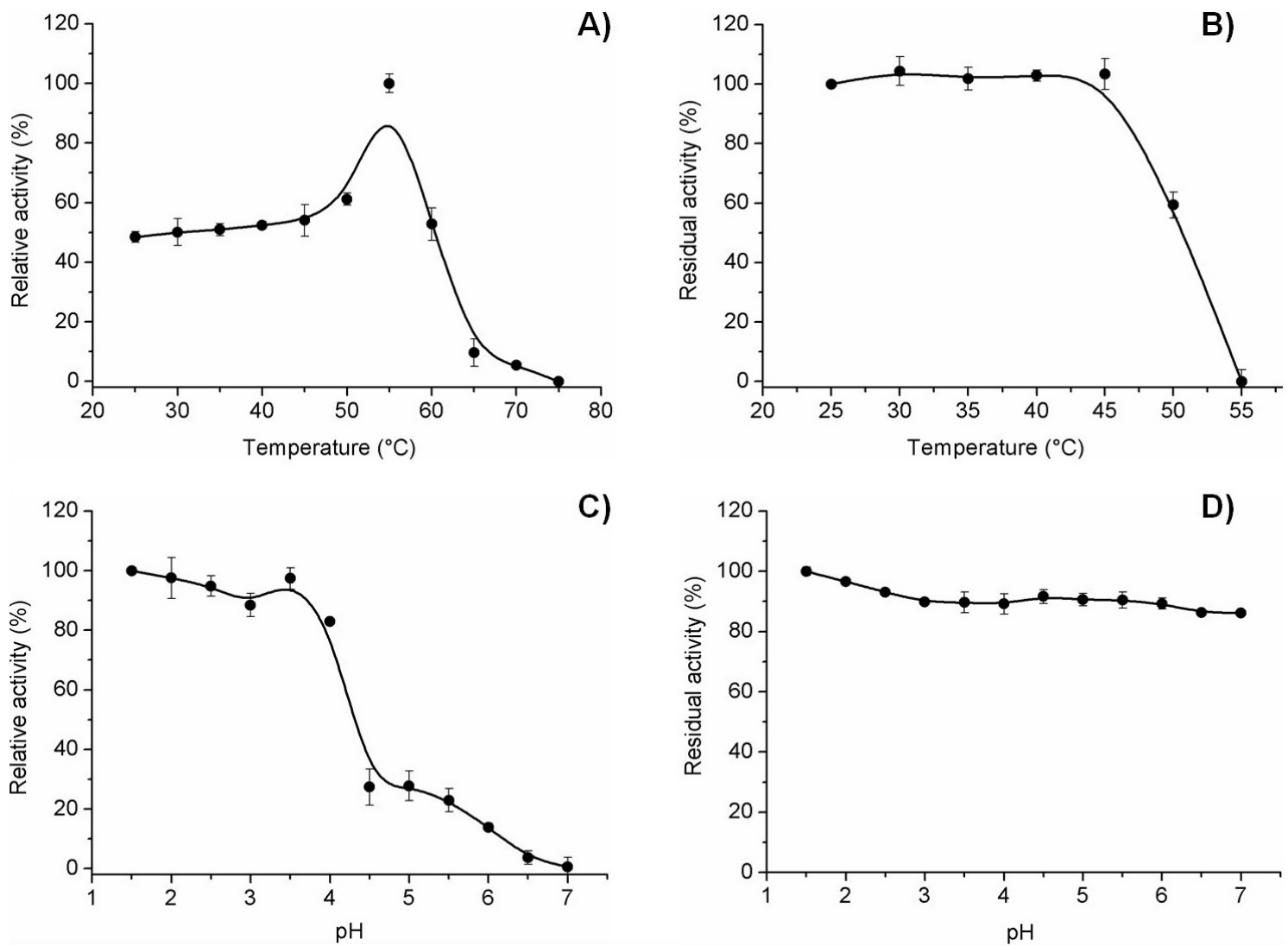

Figure 2. $\mathrm{pH}$ and temperature effect on EE acidic proteases. (A) Optimal temperature; (B) Thermal stability; (C) Optimal pH; (D) pH stability.

Table 2. Effect of enzyme inhibitors and metal ions on the proteolytic activity of EE.

\begin{tabular}{lcc}
\hline Chemical Agent & Residual Activity (\%) & Inhibition (\%) \\
\hline Control & $100 \pm 4.19^{\mathrm{a}^{*}}$ & 0 \\
$\mathrm{DTT}$ & $104 \pm 3.25^{\mathrm{b}}$ & 0 \\
Pepstatin A & $0^{\mathrm{c}}$ & 100 \\
$\mathrm{~Pb}^{2+}$ & $85 \pm 0.10^{\mathrm{d}}$ & 15 \\
$\mathrm{Mg}^{2+}$ & $87 \pm 3.35^{\mathrm{e}}$ & 13 \\
$\mathrm{Al}^{3+}$ & $89 \pm 1.20^{\mathrm{f}}$ & 11 \\
$\mathrm{Mn}^{2+}$ & $90 \pm 2.05^{\mathrm{g}}$ & 10 \\
$\mathrm{~K}^{+}$ & $91 \pm 2.55^{\mathrm{h}}$ & 9 \\
$\mathrm{Hg}^{2+}$ & $94 \pm 0.72^{\mathrm{i}}$ & 6 \\
$\mathrm{Cd}^{2+}$ & $97 \pm 2.16^{\mathrm{j}}$ & 3 \\
$\mathrm{Cu}^{2+}$ & $98 \pm 5.51^{\mathrm{k}}$ & 2 \\
$\mathrm{Ca}^{2+}$ & $101 \pm 1.08^{\mathrm{l}}$ & 0 \\
\hline $\mathrm{Diffe}^{2+}$ & & \\
\hline
\end{tabular}

*Different superscript letters mean statistical differences in relation to control, according to the Tukey test $(p<0.05)$. formation of the enzyme-substrate complex. Thus, the result of this test indicates that $\mathrm{EE}$ acidic proteases belong to the class of aspartic proteases, as well as pepsins, and because they are stomach enzymes, they are probably of the pepsin-like type. Similar results were found in studies using crude, or partially purified, stomach extracts from fish, in which a high inhibition of acidic proteolytic activity was observed (Bkhairia et al., 2016; Acevedo Gomez et al., 2018). Fish pepsins are strongly inhibited by pepstatin A (Klomklao et al., 2007; Wu et al., 2009; Nalinanon et al., 2010; Cao et al., 2011). The reducing agent dithiotreitol (DTT) did not promote significant changes in the proteolytic activity of EE, which indicates that these aspartic proteases present no disulfide bridges in their native structure.

It is widely known that calcium interacts with some proteins, enhancing its stability. The interaction of calcium with proteases has been reported in several studies, but the stabilization mechanism is not yet fully understood (Kotorman et al., 2003). However, for C. hippos digestive aspartic proteases, $\mathrm{Ca}^{2+}$ did not promote a significant effect on the tested concentration. The proteolytic activity of L. aurata digestive acidic protease was also not affected by $\mathrm{Ca}^{2+}$ and Bkhairia et al. (2016) stated that this finding presents a factor for a potential use of the enzyme in food processing, such as in the production of dairy products. All other metals tested promoted mild EE activity inhibition, which varied between $3 \%$ and $15 \%$. The way 
in which the activity of digestive proteases decreases in the presence of some metal ions is not fully understood. However, it is suggested that these metals may influence the interaction of the enzyme with the substrate at the active site (Sila et al., 2012) or they bind to other regions forming salts with these proteins leading to denaturation. The resistance to the presence of these elements is an interesting characteristic of $C$. hippos acidic proteases that could be used without the need to remove metals present in the process.

Acevedo Gomez et al. (2018) reported that the addition of $\mathrm{Mg}^{2+}$ stimulated the activity of $P$. lineatus digestive aspartic proteases, increasing the activity by approximately $10 \%$, while in crevalle jack this ion inhibited $13 \%$ of the EE acidic proteolytic activity. Klomklao et al. (2007) showed that the activity of $C$. pectoralis pepsins was potentiated by the divalent cations $\mathrm{Ca}^{2+}$ and $\mathrm{Mg}^{2+}$.

\subsection{Effect of $\mathrm{NaCl}$ on EE acidic proteolytic activity}

The effect of $\mathrm{NaCl}$ at different concentrations on the activity of EE acidic proteases is shown in Figure 3. It can be seen that the proteolytic activity decreased continuously with the increase in $\mathrm{NaCl}$ concentrations. However, the enzyme maintained a high activity even in the presence of $15 \% \mathrm{NaCl}$.

Similar results were found by Acevedo Gomez et al. (2018) for commercial porcine pepsin and digestive aspartic proteases from $P$. lineatus. It was similarly reported for acidic proteases from the stomach crude extract of $P$. gigas and for pepsins from C. pectoralis (Klomklao et al., 2007; Vannabun et al., 2014), whereas pepsins from S. aurita, after incubation with $10 \%$ of $\mathrm{NaCl}$, showed proteolytic activity of approximately 20\% (Khaled et al., 2011). Klomklao et al. (2007, 2009) emphasize that high $\mathrm{NaCl}$ concentration promotes an increase in protein-protein interactions, which may lead to precipitation. In addition, as they are hydrolase class enzymes, competition with salt for water molecules would hinder their catalysis.

In view of the results presented, it can be concluded that through a simple step of salting-out it was possible to obtain a protein concentrate containing two isoforms of aspartic proteases, with high proteolytic activity, from the $C$. hippos

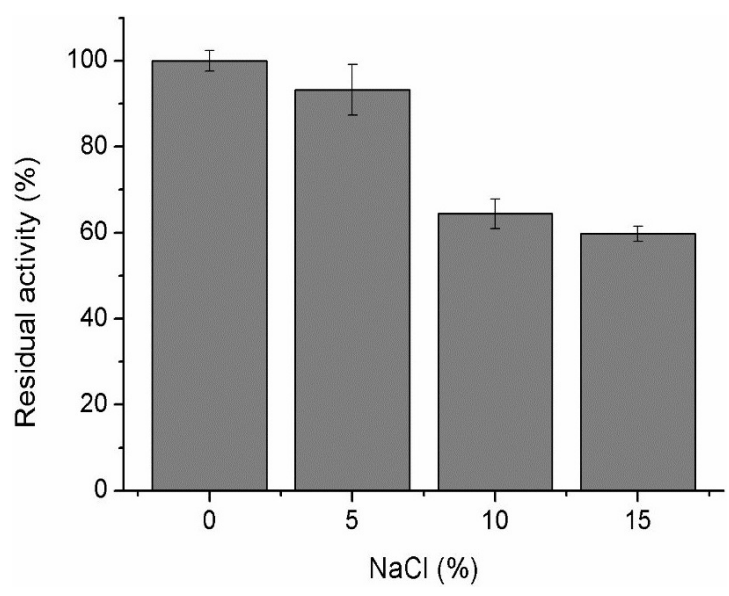

Figure 3. Effect of $\mathrm{NaCl}$ on the $\mathrm{EE}$ acidic proteases. stomach crude extract. The physicochemical characteristics determined demonstrate that these enzymes presenting similar characteristics found for pepsins isolated from fishes and have potential for industrial and biotechnological applications.

\section{Acknowledgements}

The authors would like to thank the fisherman and fishmonger Francisco Assis de Melo and the Shalom fish market for donating fish processing residues. This work was funded by Coordenação de Aperfeiçoamento de Pessoal de Nível Superior (CAPES), Conselho Nacional de Desenvolvimento Científico e Tecnológico (CNPq) and Financiadora de Estudos e Projetos (FINEP).

\section{References}

ACEVEDO GOMEZ, A.V., GOMEZ, G., CHAMORRO, E., BUSTILLO, S. and LEIVA, L.C., 2018. Digestive aspartic proteases from sábalo (Prochilodus lineatus): characterization and application for collagen extraction. Food Chemistry, vol. 269, pp.610-617. http:// dx.doi.org/10.1016/j.foodchem.2018.07.043. PMid:30100479.

BKHAIRIA, I., BEN KHALED, H., KTARI, N., MILED, N., NASRI, M. and GHORBEL, S., 2016. Biochemical and molecular characterization of a new alkaline trypsin from Liza aurata: structural features explaining thermal stability. Food Chemistry, vol. 196, pp. 1346-1354. http://dx.doi.org/10.1016/j.foodchem.2015.10.058. PMid:26593626.

BOUGATEF, A., BALTI, R., ZAIED, S.B., SOUISSI, N. and NASRI, M., 2008. Pepsinogen and pepsin from the stomach of smooth hound (Mustelus mustelus): Purification, characterization and amino acid terminal sequences. Food Chemistry, vol. 107, no. 2, pp. 777-784. http://dx.doi.org/10.1016/j.foodchem.2007.08.077.

BRADFORD, M.M., 1976. A rapid and sensitive method for the quantitation of microgram quantities of protein utilizing the principle of protein-dye binding. Analytical Biochemistry, vol. 72, no. 1-2, pp. 248-254. http://dx.doi.org/10.1016/00032697(76)90527-3. PMid:942051.

BRASIL. Ministério da Pesca e Aquicultura - MPA, 2011. Boletim estatístico da pesca e aquicultura. Brasília: Ministério da Pesca e Aquicultura, $60 \mathrm{p}$.

CANDIOTTO, F.B., FREITAS-JÚNIOR, A.C.V., NERI, R.C.A., BEZERRA, R.S., RODRIGUES, R.V., SAMPAIO, L.A. and TESSER, M.B., 2018. Characterization of digestive enzymes from captive Brazilian flounder Paralichthys orbignyanus. Brazilian Journal of Biology = Revista Brasleira de Biologia, vol. 78, no. 2, pp. 281-288. http:// dx.doi.org/10.1590/1519-6984.06616. PMid:28832833.

CAO, M., YU, C. and ANDERSON, B.D.O., 2011. Formation control using range-only measurements. Automatica, vol. 47, no. 4, pp. 776-781. http://dx.doi.org/10.1016/j.automatica.2011.01.067.

COSTA, H.M.S., FREITAS-JÚNIOR, A.C.V., AMARAL, I.P.G., HIRATA, I.Y., PAIVA, P.M.G., CARVALHOJUNIOR, L.B., OLIVEIRA, V. and BEZERRA, R.S., 2013. Metal-sensitive and thermostable trypsin from the crevalle jack (Caranx hippos) pyloric caeca: purification and characterization. Chemistry Central Journal, vol. 7, no. 1, pp. 166173. http://dx.doi.org/10.1186/1752-153X-7-166. PMid:24112762.

ESPÓSITO, T.S., MARCUSCHI, M., AMARAL, I.P.G., CARVALHO, L.B. Jr. and BEZERRA, R.S., 2010. Trypsin from the Processing Waste of the Lane Snapper (Lutjanus synagris) and Its Compatibility with Oxidants, Surfactants and Commercial Detergents. Journal of Agricultural and Food Chemistry, vol. 58, no. 10, pp. 6433-6439. http://dx.doi.org/10.1021/jf100111e. PMid:20426469. 
FRANÇA, R.C.P., ASSIS, C.R.D., SANTOS, J.F., TORQUATO, R.J.S., TANAKA, A.S., HIRATA, I.Y., ASSIS, D.M., JULIANO, M.A., CAVALLI, R.O., CARVALHO JUNIOR, L.B. and BEZERRA, R.S., 2016. Bovine pancreatic trypsin inhibitor immobilized onto sepharose as a new strategy to purify a thermostable alkaline peptidase from cobia (Rachycentron canadum) processing waste. Journal of Chromatography. B, Analytical Technologies in the Biomedical and Life Sciences, vol. 1033-1034, pp. 210-217. http://dx.doi. org/10.1016/j.jchromb.2016.08.028. PMid:27567377.

FREITAS-JÚNIOR, A.C.V. and BEZERRA, R.S., 2015. Aproveitamento Integral do Pescado: novos horizontes para o fortalecimento da cadeia produtiva. Panorama da Aquicultura, vol. 2, pp. 48-53.

FREITAS-JÚNIOR, A.C.V., COSTA, H.M.S., ICIMOTO, M.Y., HIRATA, I.Y., MARCONDES, M., CARVALHO, L.B. Jr., OLIVEIRA, V. and BEZERRA, R.S., 2012. Giant Amazonian fish pirarucu (Arapaima gigas): its viscera as a source of thermostable trypsin. Food Chemistry, vol. 133, no. 4, pp. 1596-1602. http://dx.doi.org/10.1016/j. foodchem.2012.02.056.

GARCÍA-CARREÑO, F.L., DIMES, L.E. and HAARD, N.F., 1993. Substrate-Gel Electrophoresis for composition and molecular weight of proteinases or proteinaceous proteinase inhibitors. Analytical Biochemistry, vol. 214, no. 1, pp. 65-69. http://dx.doi. org/10.1006/abio.1993.1457. PMid:8250256.

KHALED, H.B., GHORBEL-BELLAAJ, O., HMIDET, N., JELLOULI, K., ALI, N.E.H., GHORBEL, S. and NASRI, M., 2011. A novel aspartic protease from the viscera of Sardinelle (Sardinella aurita): purification and characterisation. Food Chemistry, vol. 128, no. 4, pp. 847-853. http://dx.doi.org/10.1016/j.foodchem.2011.03.104.

KLOMKLAO, S., BENJAKUL, S., VISESSANGUAN, W., KISHIMURA, H. and SIMPSON, B.K., 2007. Purification and characterization of trypsins from the spleen of skipjack tuna (Katsuwonus pelanis). Food Chemistry, vol. 100, no. 4, pp. 1580-1589. http://dx.doi. org/10.1016/j.foodchem.2006.01.001.

KLOMKLAO, S., KISHIMURA, H., BENJAKUL, S. and SIMPSON, B.K., 2009. Autolysis and biochemical properties of endogenous proteinases in Japanese sandfish (Arctoscopus japonicus). International Journal of Food Science E Technology, vol. 44, no. 7, pp. 1344-1350. http://dx.doi.org/10.1111/j.13652621.2009.01963.x.

KOTORMÁN, M., LACZKÓ, I., SZABÓ, A. and SIMON, L.M., 2003. Effects of $\mathrm{Ca}^{2+}$ on catalytic activity and conformation of trypsin and $\alpha$-chymotrypsin in aqueous ethanol. Biochemical and Biophysical Research Communications, vol. 304, no. 1, pp. 18-21. http:// dx.doi.org/10.1016/S0006-291X(03)00534-5. PMid:12705877.

LUQUE, J.L. and ALVES, D.R., 2001. Ecologia das comunidades de metazoários parasitos, do xaréu, Caranx hippos (Linnaeus) e do xerelete, Caranx tatus Agassiz (Osteichthyes, Carangidae) do litoral do estado do Rio de Janeiro, Brasil. Revista Brasileira de Zoologia, vol. 18, no. 2, pp. 399-410. http://dx.doi.org/10.1590/ S0101-81752001000200011.

MEDEIROS, F.S., MARCUSCHI, M., ASSIS, C.R.D., SILVA, J.F., ESPÓSITO, T.S. and BEZERRRA, R.S., 2015. [viewed 15 February 2020]. Potencial laundry detergent applications of mutton snapper (Lutjanus analis) proteases. Journal of FisheriesSciences.Com, vol. 9, pp. 63-69.
MIURA, Y., KAGEYAMA, T. and MORIYAMA, A., 2015. Pepsinogens and pepsins from largemouth bass, Micropterus salmoides: purification and characterization with special reference to high proteolytic activities of bass enzymes. Comparative Biochemistry and Physiology. Part B, Biochemistry \& Molecular Biology, vol. 183, pp. 42-48. http://dx.doi.org/10.1016/j.cbpb.2015.01.001. PMid:25608034.

MOTWANI, H.V., DE ROSA, M., ODELL, L.R., HALLBERG, A. and LARHED, M., 2015. Aspartic protease inhibitors containing tertiary alcohol transition-state mimics. European Journal of Medicinal Chemistry, vol. 90, pp. 462-490. http://dx.doi. org/10.1016/j.ejmech.2014.11.036. PMid:25481814.

NALINANON, S., BENJAKUL, S. and KISHIMURA, H., 2010. Biochemical properties of pepsinogen and pepsin from the stomach of albacore tuna (Thunnus alalunga). Food Chemistry, vol. 121, no. 1, pp. 49-55. http://dx.doi.org/10.1016/j.foodchem.2009.11.089.

PAVLISKO, A., RIAL, A., VECCHI, S. and COPPES, Z., 1997. Properties of pepsin and trypsin isolated from the digestive tract of Parona signata "palometa. Journal of Food Biochemistry, vol. 21, no. 3, pp. 289-308. http://dx.doi.org/10.1111/j.1745-4514.1997.tb00210.x.

SILA, A., NASRI, R., JRIDI, M., BALTI, R., NASRI, M. and BOUGATEF, A., 2012. Characterisation of trypsin purified from the viscera of Tunisian barbell (Barbus callensis) and its application for recovery of carotenoproteins from shrimp wastes. Food Chemistry, vol. 132, no. 3, pp. 1287-1295. http://dx.doi.org/10.1016/j. foodchem.2011.11.105. PMid:29243613.

TANJI, M., YAKABE, E., KAGEYAMA, T., YOKOBORI, S., ICHINOSE, M., MIKI, K., ITO, H. and TAKAHASHI, K.,2007. Purification and characterization of pepsinogens from the gastric mucosa of African coelacanth, Latimeria chalumnae, and properties of the major pepsins. Comparative Biochemistry and Physiology. Part B, Biochemistry E Molecular Biology, vol. 146, no. 3, pp. 412-420. http://dx.doi.org/10.1016/j.cbpb.2006.11.025. PMid:17258488.

VANNABUN, A., KETNAWA, S., PHONGTHAI, S., BENJAKUL, S. and RAWDKUEN, S., 2014. Characterization of acid and alkaline proteases from viscera of farmed giant catfish. Food Bioscience, vol. 6, pp. 9-16. http://dx.doi.org/10.1016/j.fbio.2014.01.001.

WU, T., SUN, L.-C., DU, C.-H., CAI, Q.-F., ZHANG, Q.-B., SU, W.-J. and CAO, M.-J., 2009. Identification of pepsinogens and pepsins from the stomach of European eel (Anguilla anguilla). Food Chemistry, vol. 115, no. 1, pp. 137-142. http://dx.doi.org/10.1016/j. foodchem.2008.11.077.

ZHAO, L., BUDGE, S.M., GHALY, A.E., BROOKS, M.S. and DAVE, D., 2011. Extraction, purification and characterization of fish pepsin: a critical review. Journal of Food Processing E Technology, vol. 2, no. 6, pp. 126-139. http://dx.doi.org/10.4172/2157-7110.1000126.

ZHOU, Q., FU, X., ZHANG, J., SU, W. and CAO, M., 2007. Purification and characterization of sea bream (Sparus latus Houttuyn) pepsinogens and pepsins. Food Chemistry, vol. 103, no. 3, pp. 795-801. http://dx.doi.org/10.1016/j.foodchem.2006.09.021.

ZHOU, Q., LIU, G., HUANG, Y., WENG, L., HARA, K., SU, W. and CAO, M., 2008. Pepsinogens and pepsins from Mandarin Fish (Siniperca chuatsi). Journal of Agricultural and Food Chemistry, vol. 56, no. 13, pp. 5401-5406. http://dx.doi.org/10.1021/ jf800458n. PMid:18543931. 